University of Nebraska - Lincoln

DigitalCommons@University of Nebraska - Lincoln

Community and Regional Planning Program:

Faculty Scholarly and Creative Activity

Community and Regional Planning Program

2008

Evaluating Local Coastal Zone Land Use Planning Capacities in

California

Zhenghong Tang

University of Nebraska - Lincoln, ztang2@unl.edu

Follow this and additional works at: https://digitalcommons.unl.edu/arch_crp_facultyschol

Part of the Urban, Community and Regional Planning Commons

Tang, Zhenghong, "Evaluating Local Coastal Zone Land Use Planning Capacities in California" (2008). Community and Regional Planning Program: Faculty Scholarly and Creative Activity. 2.

https://digitalcommons.unl.edu/arch_crp_facultyschol/2

This Article is brought to you for free and open access by the Community and Regional Planning Program at DigitalCommons@University of Nebraska - Lincoln. It has been accepted for inclusion in Community and Regional Planning Program: Faculty Scholarly and Creative Activity by an authorized administrator of DigitalCommons@University of Nebraska - Lincoln. 
Published in Ocean \& Coastal Management 51:7 (2008), pp. 544-555; doi 10.1016/j.ocecoaman.2008.06.001

Copyright @ 2008 Elsevier Ltd. Used by permission. http://www.elsevierficom/locate/ocecoaman

Published online June 12, 2008.

\title{
Evaluating Local Coastal Zone Land Use Planning Capacities in California
}

\author{
Zhenghong Tang \\ Community and Regional Planning Program, 302 Architecture Hall, University of Nebraska-Lincoln, \\ Lincoln, NE 68588-0105, USA; Email zhenghong.tang@gmailficom or ztang2@unl.edu
}

\begin{abstract}
Local jurisdictions' coastal zone land use plans play an important role in protecting critical coastal resources and ensuring coastal communities' sustainable development. This study extends the previous national and regional measurement systems to local coastal zone land use planning. This study evaluates 46 California local jurisdictions' coastal zone land use plans and analyzes the factors influencing local coastal zone land use planning capacities. The descriptive results show that planning quality varied widely in scope and content, and did not fully utilize available coastal management tools and mechanisms to influence local development patterns. The regression results further highlight the influence of planning capacity, public participation, environmental sensitivity, and contextual characteristics. Six policy recommendations are provided to improve local coastal zone land use planning capacities.
\end{abstract}

\section{Introduction}

Coastal zones are a focus of major economic, industrial, recreational, and social activity. Rapid coastal development has placed greater pressure on coastal resources and presented significant challenges to coastal sustainability. The Coastal Zone Management Act (CZMA) of 1972 declared a national interest in the effective management, beneficial use, protection, and development of the coastal zone and established a framework for a federal and state coastal management partnership to balance economic growth with coastal protection. The CZMA has relied on state-approved "Local Coastal Programs" for implementation [1]. Although the federal agencies have a strong political interest in coastal management, their limited authority over local land use and development patterns usually restricts their ability to influence local land use decision-making [2]. Since local coastal zone land use planning is directly connected to coastal resources and land development, it significantly impacts state and national interests. Local coastal zone land use plans can identify and address critical issues including coastal resources, sensitive lands, hazards areas, coastal access, use priorities, and significant impacts of development on coastal zones. Some recent studies have identified the influence of local coastal zone land use planning on coastal zone management [3-5].

Numerous efforts have been made to evaluate the processes and outcomes of coastal zone management programs under the CZMA. Some initial studies [6,7] assessed national coastal zone management program policies and pointed out relevant problems and opportunities. An early study comprehensively measured the implementation of coastal zone management between 1972 and
1990, and suggested further qualitative implementation measures [8]. A later study further evaluated coastal zone management program activities since 1975 and found that they varied considerably in intent, approach, scope, and findings [9]. A special series of articles measured National Coastal Zone Management effectiveness through a systematic assessment of the 29 approved coastal programs undertaken between 1995 and 1997 [9-13]. They concluded that the state coastal zone management programs were effectively implementing the core national objectives. Later, the Office of Ocean and Coastal Resource Management in the National Oceanic and Atmospheric Administration (NOAA) developed a performance measurement system to regularly assess the national impact of CZMA programs and to demonstrate the effectiveness of coastal zone management programs. Besides the national effectiveness studies on CZMA, some studies also focused on regional coastal zone management effectiveness. A survey study interviewed 260 coastal managers to compare regional and state perceptions of the performance of state coastal zone management programs [14]. A recent study further evaluated 15 regional coastal zone management plans and pointed out their strengths and weaknesses [1]. Most of these studies focused on the effectiveness of coastal zone management at national, state, or regional levels; however, few studies have measured local coastal zone land use planning quality and capacity.

This study extends the previous national and regional measurement systems to local coastal zone land use planning in California's coastal jurisdictions. More specifically, this study will address many critical questions listed in NOAA's most recent discussion paper addressing current and future challenges for coastal 


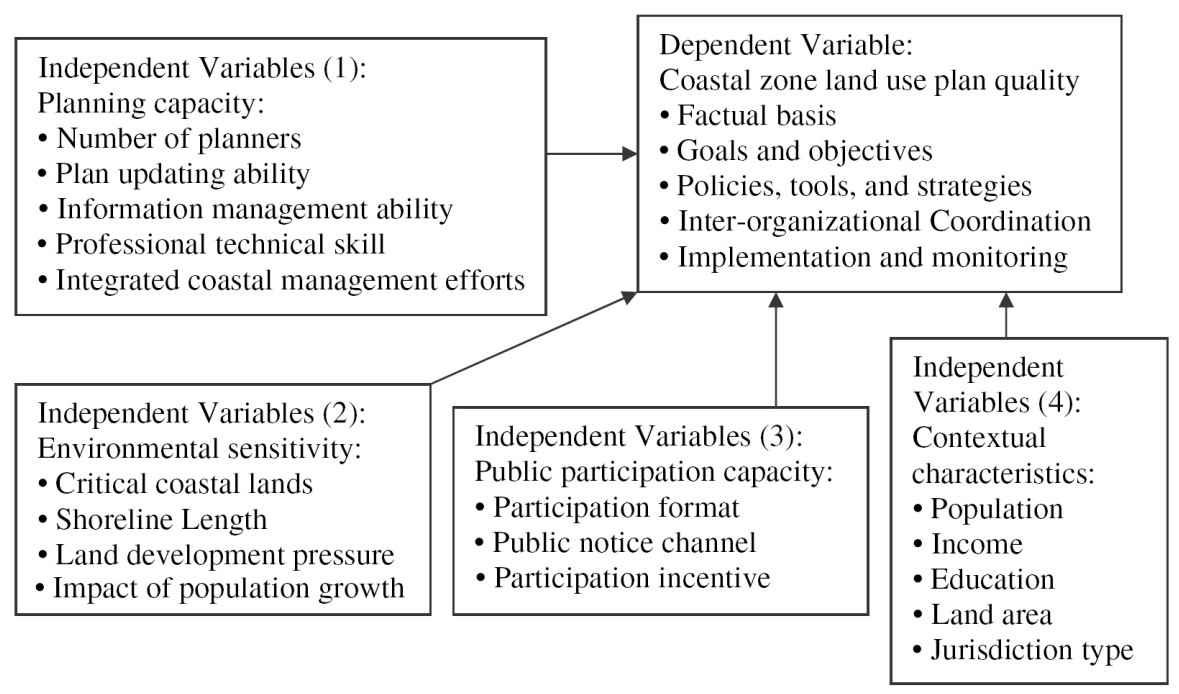

Figure 1. A conceptual model of local coastal zonel and use plan quality.

management [15]: What are the critical issues in coastal zone management and should there be a higher priority for some issues than for others? Are local governments appropriately engaged in coastal management? Do local governments have the appropriate capacities to manage coastal issues?

Therefore, this study addresses these specific research questions about the degree to which the coastal jurisdictions of the Pacific states have adequately addressed local coastal zone land use planning. This study specifies the research questions as follows: (1) What are the plan components and indicators that receive the greatest attention in California local coastal zone plans; (2) Do California local coastal zone land use plans vary in quality? (3) Which factors influence the quality of local land use plans? and (4) How can local planning processes be improved to enhance coastal zone quality and effectiveness?

The conceptual model has been developed to measure coastal zone land use quality and identify the factors influencing it.

Based on this conceptual model, this study first conceptualizes the quality of local coastal zone land use plans and then analyzes the four sets of major factors influencing the quality.

\section{Conceptualization of coastal zone land use plan quality}

A breakthrough for land use plan quality evaluation is to conceptualize an evaluation framework as fact basis, goals, and policies to analyze the influence of state planning mandates on local plan quality $[16,17]$. In the mid-1990s, scholars identified a series of indicators for quantitatively assessing plan quality. Some recent plan quality studies extended this concept of plan quality by adding two components - inter-jurisdictional coordination and implementation - to further measure the ability of local plans to manage ecosystems $[18,19]$. Recent studies of plan quality have primarily analyzed the quality of local land use plans [20-24]. Although major achievements were made in previous studies, few studies, if any, have systematically examined the quality and capacities of local jurisdictions in coastal zone land use planning.

Based on the literature on plan quality, this study proposes to measure the ability of local jurisdictions for coastal zone land use planning. A local coastal zone land use plan must specify the existing coastal conditions and identify needs related to coastal zone development as well as represent general aspirations, objectives and needs. Thus, competing missions, objectives, values, physi- cal and socioeconomic conditions are brought together into a local plan. More importantly, a high quality coastal zone land use plan represents a collaborative vision for coastal zone management. A strong guide to strategies, policies, and tools of coastal zone management is essential for a local plan. Furthermore, a local coastal zone land use plan needs to indicate how to implement the plan and how to coordinate with others.

By combining existing concepts of plan quality with theoretically driven coastal zone land use planning, this study has developed a framework with five critical components to measure local coastal zone land use planning capacities. These components include (1) factual basis, (2) goals and objectives, (3) policies, tools, and strategies, (4) inter-organizational coordination, and (5) implementation and monitoring. These five core plan components provide a framework to measure the quality of a local coastal zone land use plan in coastal zone management. Under this framework, detailed indicators will be developed within each component to explain the key points that comprise a strong plan. When aggregated, these indicators can be statistically measured to compare the quality of plans across multiple jurisdictions. The National Coastal Management Program performance measure highlighted six critical coastal issues in coastal management: coastal habitats, coastal hazards, coastal water quality, coastal dependent uses and community development, public access, and government coordination and decision-making $[15,25]$. This study integrates these six categories into the five plan components which will be explained in the following section.

\subsection{Factual basis}

The factual basis of a local land use plan should identify existing local conditions and the need for community physical development [16]. A local coastal zone land use plan must contain a factual base describing coastal conditions and elements for development. Specially, coastal zone land use planning should identify the major coastal zone management laws and regulations (e.g. CZMA and state coastal zone management acts) that are the legitimate foundation for local coastal zone management. In addition, local jurisdictions' coastal zone boundary delineates the planning scope for coastal zone management. A local coastal zone plan should identify and map physical boundaries. Since the coastal zone is rich in a variety of natural, ecological, and environmen- 
tal resources that are critical for present and future generations, coastal zone plans must identify significant natural resources and environmentally sensitive lands (e.g. shorelands, forestry, wetlands, floodplains, estuaries, beaches, dunes, barrier islands, coral reefs, and fish and wildlife habitat). Moreover, important cultural, historic, and esthetic values in coastal zones, which are essential to all citizens, should be preserved in local coastal zone plans. The physical settings of local coastal zone plans also include coastal disaster vulnerable areas that are subject to erosion, earthquakes, flooding, hurricanes, tsunamis, land subsidence, and other hazards. Due to intense residential, commercial, and industrial use of coastal areas, coastal water and water quality issues have become important components in local coastal land use planning. Critical facilities and services (e.g. hospitals, police stations, and nursing homes) within the coastal zone should be addressed in local coastal zone plans. In addition, coastal land use plans should identify transportation, roads, and coastal access points. The plans also should predict economic development, population growth, recreational and tourism needs that can eventually cause increasing and competing demands upon the land and waters of coastal zone areas. Coastal environmental problems and potential conflicts such as coastal pollution, loss of habitat, and salinization, should also be considered in coastal zone plans. Some recent studies have suggested that global warming may result in a substantial rise in sea level [26] thus, coastal plans must anticipate such possible serious adverse effects.

\subsection{Goals and objectives}

Goals and objectives that are through, long-term, consistent, and clear lead to the formulation, adoption, and implementation of effective strategies in local land use plans [2,22]. This study has adopted seven national goals of NOAA's performance measurement system to measure whether they have been implemented in local coastal zone land use plans. These seven goals are: (1) to protect and restore significant coastal resources; (2) to prevent, reduce, or remediate polluted runoff to coastal waters; (3) to protect life and property in hazardous areas and build disaster-resistant, healthy, safe communities; (4) to promote sustainable growth in coastal communities; (5) to provide for priority water-dependent uses; (6) to improve public shoreline access; and (7) to improve government coordination and decision-making.

\subsection{Policies, tools, and strategies}

Policies, tools, and strategies represent the heart of a plan because they are the means for realizing plan goals and objectives and set forth specific principles of land use design and development management [17] as well as reflect a clear commitment to guide decision-making in local jurisdictions. A wide variety of policies, tools, strategies, and programs are used to influence the location, type, intensity, design, quality and timing of coastal zone development $[1,9]$.

This study has categorized the major planning policies, tools, strategies, and programs as nine types: (1) Development regulations: development regulations usually regulate the location, type, and intensity of new development [27] and have been widely used in coastal zone management practice since they can provide the most direct approach for local land use management. (2). Building standards: building standards can set detailed criteria for building construction. (3). Property acquisition programs: land acquisition has been an important program for coastal areas. Property acquisition programs refer to acquisition of land through purchasing properties in certain areas with public funds, bond measures, and private donations from land trusts and conservancies. (4). Incentive tools: incentive tools are non-mandatory strategies that can be used to stimulate incentives for effective coastal zone management. (5). In- formation dissemination strategies: information dissemination strategies are widely identified as a critical component of effective planning by reflecting a commitment to the principles of democratic governance. $(6,7)$. Critical and public facilities policies: critical and public facilities help enhance long-term capital improvement programs, build schools and .re stations, storm sewers, and other public utilities. (8). Financial tools: financial tools are a way of using more equitable policies to distribute the public costs of private development. and (9). Private-sector initiatives: private-sector initiatives include land trusts and public-private partnerships for specific coastal areas [28].

\subsection{Inter-organizational coordination}

Inter-organizational coordination identifies the need to coordinate with other agencies, jurisdictions and landowners to develop a high quality plan $[18,19]$. Inter-organizational coordination emphasizes that coastal issues are complex, cross-boundary, dynamic, dispersed and multiple-scale. Therefore, effective coastal land use plans require a wide range of expertise to understand these unique problems and an even wider range of agencies to find and implement solutions. Inter-organizational coordination is an umbrella framework for all the agencies providing collaborative services at the local level.

\subsection{Implementation and monitoring}

Implementation and monitoring measure the ability of a plan to implement policies, tools and strategies, establish a framework for promoting systems for coastal zone land use planning, determine how well the plan meets its goals and objectives, and identify opportunities for improving the performance of coastal zone actions where needed. Implementation and monitoring mechanisms should be identified in local coastal zone land use plans. A detailed evaluation protocol for coastal zone land use plan quality is developed based on the definitions of coastal plan quality.

\section{Factors influencing coastal zone land use plan quality}

Local coastal zone land use planning is a complex process embracing geographic, social and economic settings and is affected by many factors including jurisdiction framework, planners' values and experiences, information resources, and awareness of alternatives. Although some studies have discussed the factors influencing land use planning or coastal management $[20,23,24]$, little research has quantitatively measured the factors influencing the effectiveness of coastal zone land use planning. This study presents four sets of independent variables that may influence local coastal zone land use plan quality: (1) planning capacity, (2) environmental sensitivity, (3) public participation, and (4) contextual characteristics.

\subsection{Planning capacity}

Since the local planning department is the primary agency which conducts local coastal zone land use planning, planning capacity directly influences the plan quality through growth management, coastal zone land use planning, and hazards management. Planning capacity can be measured by the number of planners, plan updating ability, coastal information management ability, level of technical professionals, and integrated coastal management efforts.

\subsubsection{Number of planners}

Quality plans are associated with increased levels of personnel, financial resources, technical expertise, and commitment to a 
high quality plan [30]. Planning staffs serve as internal consultants by providing the specialized skills needed by the planners [31,32]. They handle such administrative duties as correspondence, meeting minutes, and acquiring technical resources. However, jurisdictions with understaffed planning agencies are at a distinct disadvantage when it comes to managing coastal land use for future development. The number of planners has a direct influence on the quality of local coastal zone land use planning.

\subsubsection{Plan updating ability}

Plan updating ability measures local jurisdictions' capacity on coastal zone land use planning. Local coastal zone land use planning is a dynamic process which is based on a snapshot of jurisdictional values, politics, economic, and environmental conditions in a particular planning range. Understanding how local plan quality can be improved by plan updating may provide important insights for strengthening local coastal land use quality. This study assumes more recent plan updates lead to higher plan quality. An on-time, regular plan update procedure helps a coastal plan stays current with new information, changing conditions, regulations, and techniques.

\subsubsection{Information management ability}

A critical element in a local coastal zone land use plan is managing coastal information and sharing with government officials, the judiciary, legal practitioners, academia, and the public at large. Web-based information is an effective method of public access. This indictor is measured by jurisdictions that regularly post coastal information including coastal zone maps, coastal management programs, or links to related regional, state, and federal agencies.

\subsubsection{Professional technical skills}

Technical skill has been identified as an important factor to prepare high quality plans [16]. Geographical information system (GIS) has been widely recognized as an ideal planning tool for analyzing coastal phenomena with spatial and temporal dimensions of spatial coincidence, adjacency and network through accurate identification, description, quantification and improved evaluation of spatial and temporal variability of the impacts. GIS gives coastal zone land use planners the ability to organize, store, and analyze spatial information that can visually display information to the public or decision-makers. GIS can help planners understand precisely where critical coastal resources are and the degree to which they are in need of protection and help them make proactive choices about the strategic management of these resources.

\subsubsection{Integrated coastal management efforts}

Integrated coastal management efforts can provide a framework to address critical coastal resources and potential coastal conflicts and achieve sustainable development of coastal lands. It aims to protect coastal water quality, biodiversity, open spaces, recreational resources, and the economic base of coastal lands. Integrated coastal management efforts may determine whether local jurisdictions develop integrated coastal management programs or stand-alone coastal plans. Special coastal management efforts can integrate existing multiple sources to achieve effective coastal management.

\subsection{Environmental sensitivity}

Environmental sensitivity may significantly influence local coastal zone land use planning. A jurisdiction with greater environmental sensitivity may have more environmental protection duties and possible environmental conflicts in its land use planning. Increased environmental sensitivity can be a measure of re- duced feasibility for land use patterns and is expected to dampen local elected officials' commitment to planning [23].

\subsubsection{Critical coastal lands}

Critical coastal lands play a role in open space and the natural environment. In this study, critical environment lands are measured by the percentage of conservation lands. Critical coastal lands may include public open spaces, recreational lands, critical watersheds, and wetlands. Jurisdictions with more critical coastal lands tend to feel a stronger responsibility to protect these lands and this can eventually lead to higher plan quality.

\subsubsection{Shoreline length}

Shoreline length indicates a local jurisdictions' responsibility to protect the shorelines and coastal resources. The jurisdictions with longer shorelines may need more resources and personnel to manage them.

\subsubsection{Land development pressure}

Land development pressure may alert local officials to resource threats and lead to improved planning outcomes [23]. Land development pressure can be measured by increased housing units or building permits in recent years. The more new housing units or permits increase, the more land development pressure can be expected. Land development pressures are associated with higher levels of disturbance to environment quality resulting in a greater perceived need to protect the environment.

\subsubsection{Impact of population growth}

Rapid population growth has a substantial effect on coastal land use development and may consume more natural resources and built-environment resources; at the same time, it also creates more waste and pollution. Potential land use conflicts may increase when population growth results in a greater demand for coastal development.

\subsection{Public participation}

Public participation identifies public concerns and issues, provides information and opportunities for the public to formulate and evaluate alternatives, listens to the public, and incorporates public concerns into coastal decision-making. Public participation in coastal zone land use planning creates an open and accessible decision- making process for coastal issues and achieves the goal of sustainable development in coastal communities. Public participation capacity variables will systematically determine whether public participation has enhanced the quality of coastal zone land use plans. Three factors selected to analyze public participation capacity include participation formats, public notice channels, and public participation incentives.

\subsubsection{Participation formats}

Public hearings and workshops are the most frequently used public participation methods. According to the Brown Act enacted in 1953, local jurisdictions in California must provide advance public notice of hearings and meetings which must be open to the public if no exceptions apply. Advance notice of the place and time of the public hearing must be published in the newspaper and also mailed directly to involved citizens. The public can be involved in adopting or amending a plan in a variety of ways.

\subsubsection{Public notice channels}

Multiple public participation channels can help overcome linguistic, institutional, cultural, economic, and historic barriers to achieve effective communication. Effective public participation should provide notice channels to enable the public to discuss the information and air opinions and concerns which may 
be relevant to land use decisions. Multiple public notice channels can thereby increase the accountability and transparency of land use decision-making and contribute to public awareness [33]. The most frequently used public notice channels may include the internet, newspapers, radio, television, mailed notices, and community newsletters.

\subsubsection{Public participation incentives}

Active public participation should develop incentive strategies that allow for early and meaningful public participation in coastal zone land use planning by neighborhood organizations, development representatives, business organizations and all other stakeholders. Because many neighborhoods generally lack leadership and resources for public participation, they do not have the same level of influence on final plan decision-making. Thus, public participation incentives provide a chance for local land use decisionmakers to seriously consider public concerns and actually address them. Planners can provide more incentives to foster an exchange of information and an open discussion of ideas in the public participation process. With public participation incentives, stakeholders have an opportunity to come together and work to solve possible coastal conflicts in a collaborative spirit that forms coastal community solidarity.

\subsection{Contextual characteristics}

Contextual variables can measure the influence of background information on coastal zone land use plan quality. In this study, five major factors have been used to analyze the contextual influence on plan quality.

\subsubsection{Population}

Population has been identified as an important contextual factor in local land use planning [20]. Local jurisdictions with larger populations may have more expertise, resources and financial support for local coastal zone land use planning, but may face more coastal development pressure and problems. On one hand, more population will increase pressure on carrying capacity within a local jurisdiction; thus, more coastal conflicts and problems are expected in the jurisdictions with larger populations. On the other hand, more expertise and resources may be available for coastal zone land use planning.

\subsubsection{Wealth}

Wealthy people often have more time and a greater interest in community issues [34,35]. A wealthier population may have more money, higher awareness, and more interest in coastal issues in its jurisdiction. Wealthier populations also tend to be well educated and may be more concerned about coastal protection and pursue a higher plan quality. Thus, a wealthy jurisdiction will have more financial resources and inner incentives for coastal zone land use planning and management.

\subsubsection{Education}

Education also has been identified as an important factor contributing to land use planning issues $[30,36]$. Communities with a more highly educated population can influence the planning process and encourage higher levels of coastal protection. A community with a higher education level tends to be more concerned about coastal issues and tends to have a better perception of the need for coastal protection and more enthusiasm for participating in coastal management activities.

\subsubsection{Land area}

Land area may influence local coastal zone land use planning. Larger land areas may need more personnel resources and require greater concern.

\subsubsection{Jurisdiction type}

Jurisdiction type may also influence local coastal zone land use planning quality. Some findings suggest that different types of jurisdictions may lead to varied coastal planning outcomes [23]. This study will compare coastal zone plan quality across coastal municipalities and coastal counties. This variable can detect the role of various local jurisdictions in coastal zone management.

\section{Methods}

\subsection{Sample selection}

California is an ideal study area because it has rich coastal resources and strong coastal programs at the state level. In addition, California, a state with high population density, intense land use demands, and a rapidly growing economy, is faced with pressure from population growth, environmental management, and coastal development. California's economy is the largest of any state in the United States and ranks first in plant and animal diversity and number of rare species [38]. As California's population grows, rapid urbanization and extensive land demands are expected to cause numerous conflicts and create heavy pressure on natural resources and coastal quality.

This study collected 46 coastal zone land use plans, including either stand-alone coastal plans or coastal elements in local general plans. These 46 plans cover 20 (100\%) coastal counties, and 26 $(50 \%)$ coastal municipalities. Most of the local coastal zone land use plans were collected from the online service of the California Land use Planning Information Network or local jurisdictions' planning agency web sites as well as mail requests.

For independent variables, this study has used the California Planners' annual survey data from the California Planners' Book of List (CPBOL) 2003 and 2007. The missing items in this survey were updated by a web page survey or special requests by emails or mailed requests to local jurisdictions. Two thousand census data and 2005 American Community Survey data have been used to measure the independent variables. Finally, GIS data came from the California Spatial Information Library. Data sources and measurement of independent variables are listed in Table 1.

\subsection{Scoring indicator quality}

The preceding conceptualization of coastal zone land use plan quality led to the plan evaluation coding protocol. Each component has been evaluated by scanning all elements to assess whether it has addressed the 63 indicators of the five plan components: (1) factual basis, (2) goals and objectives, (3) policies, tools, and strategies, (4) inter-organizational coordination, and (5) implementation and monitoring. Within these five components, each indicator is scored on a 0-2 scale. A score of " 0 " means the indicator is not mentioned in the plan, a score of " 1 " means that an indicator is considered but not thoroughly, and a score of " 2 " means the indicator is fully considered.

Total and component coastal zone land use plan quality are calculated by the equations as follows:

$$
\mathrm{PC}_{j}=\frac{10}{2 m_{j}} \sum_{i=1}^{m_{j}} I_{i}
$$

and

$$
\mathrm{TPQ}=\sum_{j=1}^{5} \mathrm{PC}_{j}
$$

where $P C_{j}$ represents the quality of the $j$ th plan component (ranging $0-10) ; m_{j}$ represents the number of indicators within the $j$ th 
Table 1. Independent variables

\begin{tabular}{|c|c|c|}
\hline Variables & Measurement & Sources \\
\hline Number of planners & The actual number of planners & CAPBOL, 2007 \\
\hline Plan updating ability & The actual year of plan minus 2007 & CAPBOL, 2007 \\
\hline Information management ability & $\begin{array}{l}\text { Jurisdictions that regularly post on a website any coastal } \\
\text { documents: coastal maps, current coastal programs, } \\
\text { and the links to related coastal agencies }\end{array}$ & $\begin{array}{l}\text { CAPBOL, 2005: } \\
\text { and webpage survey }\end{array}$ \\
\hline Professional technical skill & GIS layers adopted in planning & CAPBOL, 2003 ${ }^{a}$ \\
\hline Integrated coastal management efforts & $\begin{array}{l}\text { Whether local jurisdictions develop integrated coastal programs or } \\
\text { special stand-alone coastal plans }\end{array}$ & Web survey and mail requesting \\
\hline Critical environmental lands & $\begin{array}{l}\text { Approximate proportion of jurisdiction encompassing } \\
\text { sensitive natural areas. }\end{array}$ & California spatial information library \\
\hline Shoreline length & The length of shorelines California spatial information library & \\
\hline Land development pressure & Housing units changes between 2000 and 2005 & $\begin{array}{l}\text { Census, } 2000 \text { and American } \\
\text { community survey } 2005^{\mathrm{b}}\end{array}$ \\
\hline Impact of population growth & Population change from 1990 to 2000 within a jurisdiction & Census, 2000 \\
\hline Public participation format & Workshops; townhall meetings; site tours; charrettes; other & CAPBOL, $2003^{\mathrm{a}}$ \\
\hline Public notice channel & $\begin{array}{l}\text { Internet; publish in a non-English newspaper; radio/television; } \\
\text { mail beyond required } 300^{\prime} \text { radius; notices using community } \\
\text { organizations; community newsletters; other }\end{array}$ & CAPBOL, $2003^{a}$ \\
\hline Public participation incentives & $\begin{array}{l}\text { Evening meetings; provide daycare; provide transportation; } \\
\text { meet near the project site; involve youth; post minutes } \\
\text { on the internet; electronic comments; use alternative formats }\end{array}$ & CAPBOL, $2003^{\mathrm{a}}$ \\
\hline Population 2007 & Population in each jurisdiction & CAPBOL, 2007 \\
\hline Wealth & Median family income & Census, 2000 \\
\hline Education & Percentage of persons with bachelor's degree or higher, in 2000 & Census, 2000 \\
\hline Land area & Total land areas (square miles) & California spatial information library \\
\hline Jurisdiction type & County and municipalities & California spatial information library \\
\hline
\end{tabular}

a The missing items were found through further reviewing local land use general plans, or special information requesting by emails or mails to local jurisdictions.

$\mathrm{b}$ Housing units of $2005 \mathrm{~s}$ data are unenviable in some jurisdictions. This study uses the population change rates to impute the missing units.

plan component; $I_{i}$ represents the $i$ th indicator's score (ranging 0 2 ); and TPQ is the total scores of a whole plan (ranging 0-50).

This study also introduces indicator performance to measure each indicator's quality. Indicator performance includes three subitems: indicator breadth score, depth score, and total score. Indicator breadth measures the extent to which each of the indicators was addressed across all plans. Indicator depth measures the level of importance and analyzes how much importance is stated in a plan. Indicator breadth and depth are computed using the following equations:

$$
\begin{aligned}
\mathrm{IBS}_{j} & =\frac{P_{j}}{N} \\
\mathrm{IDS}_{j} & =\frac{\sum_{j=1}^{P_{j}} I_{j}}{2 P_{j}} \\
\mathrm{ITS}_{j} & =\mathrm{IBS}_{j}+\mathrm{IDS}_{j}
\end{aligned}
$$

IBS $_{j}$ is the $j$ th indicator breadth score (ranging $0-1$ ); $P_{j}$ is the number of plans that address the $j$ th indicator; $N$ is the total number of plans in the study; IDS $_{j}$ is the $j$ th indicator depth score (ranging 01 ); $I_{j}$ is the rating on the $j$ th indicator (ranging $0-2$ ); and ITS is the $j$ th indicator total score (ranging $0-2$ ).

\subsection{Data analysis}

This study measures the coastal zone land use plan quality of the 46 sampled coastal zone land use plans. The research includes two stages of data analysis: First, this study used descriptive statistics to assess the quality of the 46 sampled plans. Second, this study used multiple regression analysis to analyze the factors affecting the quality of coastal zone land use plans. The ordinary least squares technique was introduced into this study to measure what kinds of factors influence local plan quality. Four types of independent variables were then analyzed to identify which ones influence local plan quality. This study conducted related statistical tests for reliability to ensure that the ordinary least squares would yield best, linear, and unbiased estimates. There is no violation of regression assumptions regarding model specification, multicollinearity, heteroskedasticity, autocorrelation, influential data or outliers, or inter-item correlation and scale reliability.

\section{Results}

\subsection{Descriptive statistics for plan quality}

The descriptive results are listed in Table 2. As Table 2 indicates, the mean of the total score for the 46 coastal zone land use plans' quality is 23.70 out of a maximum score of 50 . The descriptive results show that the planning quality varied widely in scope and content, and did not fully utilize available coastal management tools and mechanisms to influence local coastal zone development patterns. There are large variations in quality across local jurisdictions' coastal zone land use plans.

Of the five plan components, goals and objectives received the highest score $((M=6.21)$ on a $0-10$ scale $)$ of the five plan components, meaning jurisdictions tend to set relatively obvious goals for coastal zone management. Factual basis has the second highest score $(M=5.28)$, indicating these plans make a general fine factual basis but the quality still needs to be greatly improved. Interorganizational coordination $(M=4.58)$ is lower yet, indicating these plans lack mechanisms to coordinate coastal zone management action with other organizations. Policies, tools and strategies $(M=4.39)$ is the second lowest plan component, demonstrating these plans lack specific policies and tools for effective coastal zone management. Finally, implementation $(M=3.22)$ is the lowest scoring plan component, indicating weak mechanisms for plan implementation and monitoring.

\subsection{Indicator performance}

The indicator performance results are list in Table 3.

\subsubsection{Indicator performance in factual basis component}

In the factual basis plan component, $72 \%$ of the counties identified either the CZMA or the state's major coastal zone manage- 
Table 2. Descriptive statistics for total quality and five components performance

\begin{tabular}{llccrr}
\hline & $\mathrm{N}$ & Minimum & Maximum & Mean & Standard deviation \\
\hline I. Factual basis & 46 & 3.64 & 8.18 & 5.28 & 1.15 \\
II. Goals and objectives & 46 & 3.57 & 9.29 & 6.21 & 1.59 \\
III. Policies, tools, and strategies & 46 & 2.56 & 9.07 & 4.39 & 1.20 \\
IV. Inter-organizational coordination & 46 & 3.00 & 8.33 & 3.58 & 3.22 \\
V. Implementation and monitoring & 46 & 0.83 & 41.47 & 23.70 & 1.86 \\
Total & 46 & 14.89 & & 6.51 \\
\hline
\end{tabular}

ment mandates; the depth score of 0.64 also indicates that local coastal zone land use planning still lacks a close connection with the CZMA and the state's regulations on coastal zone management. Many counties (85\%) defined coastal zone land use plan coastal zone boundaries; however, the depth score of 0.58 indicates that many of them failed to map the boundaries. All of the counties provided basic information on significant natural resources and environmentally sensitive lands (e.g. shorelands, forestry, wetlands, floodplains, estuaries, beaches, dunes, barrier islands, coral reefs, and fish and wildlife habitat). In addition, all plans identified scenic, historic areas, recreational resources, and open spaces as critical resources in coastal zone land use planning, but the depth score of 0.64 indicates that the location-specified information on these resources still need to be improved. These plans also did a relatively good job (98\%) identifying or mapping disaster vulnerable areas in coastal zone land use plans, but further detailed information was still missing (depth score $=0.74$ ) on coastal erosion, earthquakes, flooding, hurricanes, tsunamis, and land subsidence. Since coastal water and water quality has been recognized as critical issues in CZMA and five states' coastal zone management programs, 93\% of local counties (with a depth score of 0.57 ) made coastal water and water quality a priority in their plans. The socioeconomic items received relatively higher breadth score and relatively lower depth scores. Plans pointed out critical facilities and services (98\%), or transportation, roads, and coastal access points (100\%), but the locations for these facilities or coastal access points were missing. Most (98\%) of the local jurisdictions briefly estimated the growth trend of economic development, population growth and recreation, and tourism needs, but accurate growth data were unavailable in these plans giving a depth score of 0.59. Fiftynine percent of local plans pointed out either current or potential coastal environmental problems and conflicts, and the very low depth score of 0.54 indicates that these problems and conflicts are still at a general description level. Although global warming and sea level changes have been widely identified as a critical topic for coastal zone management [39], only a few (17\%) highlighted the impact of climate change, resulting in a low depth score of 0.56 .

\subsubsection{Indicator performance in goals and objectives component}

In the goals and objectives component, all local jurisdictions set goals to promote economic development (100\%); protect and restore significant coastal resources $(100 \%)$; protect life and property in hazardous areas and build disaster-resistant, healthy, safe communities (100\%); and promote sustainable growth in coastal communities $(100 \%)$. Most $(96 \%)$ of them set goals to improve public shoreline access. More than two-thirds of the counties aimed to prevent, reduce, or remediate polluted runoff to coastal waters $(78 \%)$, and $52 \%$ provided for priority water-dependent uses. However, only $41 \%$ of the plans aimed to improve government coordination and decision-making, which is consistent with the results in the coordination and implementation plan components. Although local plans showed relatively higher coverage for six of the seven goals, many plans still lack concrete objectives to fulfill these goals.
5.2.3. Indicator performance in policies, tools, and strategies component

In the policies, tools and strategies component, there are large variations among the indicators. This study also found that most land use policies and planning tools were recommended rather than mandated. This finding is partially consistent with Davis's [1] results in coastal regional plans.

\subsubsection{Development regulations}

Development regulations have been widely used in coastal zone management practice since they can provide the most direct approach for local land use management; however, they varied in both the breadth and depth scores. Residential subdivision ordinances $(100 \%)$, requirements for habitat protection or restoration $(100 \%)$, wetlands protection regulations $(100 \%)$, hazard setback ordinances (100\%), coastal vegetation protection regulations (100\%), and environmental impact assessment requirements (100\%), were among the most common elements recommended or prescribed. In addition, a majority of plans put certain limitations on shoreline development (96\%), agricultural or open space zoning (93\%), and $83 \%$ of them restricted dredging/filling. More than half of local plans adopted planned unit development $(87 \%)$, performance zoning $(63 \%)$, special overlay districts $(63 \%)$, or restrictions on shoreline armoring (63\%). The lowest coverage of the regulations includes storm water retention requirements $(41 \%)$, and dune protection (39\%). From the depth scores of these regulations, most of these development regulations were mandated by local jurisdictions for coastal zone land use planning, although several indicators were not required by some jurisdictions.

\subsubsection{Building standards}

All plans set special local standards for hazard resistance in new buildings $(100 \%)$; however, special building standards for existing buildings $(76 \%)$, or local utility codes (39\%) for coastal hazards were limited. The reason could be that some building standards usually relied on preexisting regulations and hazard plans [1]. The breadth and depth scores indicated that new buildings usually are subject to stricter standards than existing buildings and utilities.

\subsubsection{Property acquisition programs}

Acquisition of development rights or easements has been relatively widely (93\%) adopted by local plans. Some management plans recommended or initiated a process to increase land acquisitions or conservation easements through fee simple purchase of undeveloped lands in specific coastal areas (43\%), and relocating existing buildings (52\%). The depth scores also suggest that acquisition of development rights (0.66) received more attention than fee simple purchase (0.53) and relocating existing buildings (0.54) in coastal zone land use planning.

\subsubsection{Incentive tools}

Many incentive tools have been adopted for coastal zone land use planning. Many local jurisdictions adopted transfer of development rights $(85 \%)$, density bonus $(59 \%)$, or clustered development $(96 \%)$. These results are consistent with the findings from previous studies [1,9-13]. 
Table 3. Indicator breadth and depth scores

\begin{tabular}{|c|c|c|}
\hline Indicators & Breadth (percentage) & Depth \\
\hline Major coastal zone management laws and regulations & $0.72(72)$ & 0.64 \\
\hline Coastal zone boundary and maps & $0.85(85)$ & 0.58 \\
\hline Significant natural resources and environmentally sensitive lands & $1.00(100)$ & 0.82 \\
\hline Scenic and historic areas, recreational resources, and open spaces & $1.00(100)$ & 0.64 \\
\hline Disaster vulnerable areas & $0.98(98)$ & 0.74 \\
\hline Coastal water and water quality & $0.93(93)$ & 0.57 \\
\hline Critical facilities and services & $0.98(98)$ & 0.63 \\
\hline Transportation, roads, and coastal access points & $1.00(100)$ & 0.57 \\
\hline Economic development, population growth, recreation needs & $0.98(98)$ & 0.59 \\
\hline Coastal environmental issues and potential conflicts & $0.59(59)$ & 0.54 \\
\hline Global warming and sea level rise & $0.17(17)$ & 0.56 \\
\hline Protect and restore significant coastal resources & $1.00(100)$ & 0.77 \\
\hline Prevent, reduce polluted runoff to coastal waters & $0.78(78)$ & 0.68 \\
\hline Protect life and property in hazardous areas and build disaster-resistant, healthy, safe community & $1.00(100)$ & 0.79 \\
\hline Promote sustainable growth in coastal communities & $1.00(100)$ & 0.90 \\
\hline Provide for priority water-dependent uses & $0.52(52)$ & 0.52 \\
\hline Improve public shoreline access & $0.96(96)$ & 0.82 \\
\hline Improve government coordination and decision-making & $0.41(41)$ & 0.71 \\
\hline Residential subdivision ordinances & $1.00(100)$ & 0.76 \\
\hline Planned unit development & $0.87(87)$ & 0.69 \\
\hline Special overlay districts & $0.63(63)$ & 0.60 \\
\hline Agricultural or open space zoning & $0.93(93)$ & 0.69 \\
\hline Performance zoning & $0.63(63)$ & 0.55 \\
\hline Hazard setback ordinances & $1.00(100)$ & 0.70 \\
\hline Storm water retention requirements & $0.41(41)$ & 0.55 \\
\hline Environmental impact assessment requirements & $1.00(100)$ & 0.88 \\
\hline Limitation of shoreline development & $0.96(96)$ & 0.59 \\
\hline Restrictions on shoreline armoring & $0.63(63)$ & 0.50 \\
\hline Restrictions on dredging/filling & $0.83(83)$ & 0.58 \\
\hline Dune protection regulations & $0.39(39)$ & 0.58 \\
\hline Wetlands protection regulations & $1.00(100)$ & 0.72 \\
\hline Coastal vegetation protection regulations & $1.00(100)$ & 0.50 \\
\hline Requirements for habitat protection/restoration & $1.00(100)$ & 0.78 \\
\hline Special local standards for hazard resistance in new buildings & $1.00(100)$ & 0.70 \\
\hline Special local hazard retrofit standards for existing buildings & $0.76(76)$ & 0.50 \\
\hline Special local utility codes & 0.39 (39) & 0.50 \\
\hline Fee simple purchase of undeveloped lands & $0.43(43)$ & 0.53 \\
\hline Acquisition of development rights or easements & $0.93(93)$ & 0.66 \\
\hline Relocating existing buildings & $0.52(52)$ & 0.54 \\
\hline Transfer of development rights & $0.85(85)$ & 0.69 \\
\hline Density bonuses & $0.59(59)$ & 0.61 \\
\hline Clustered development & $0.96(96)$ & 0.76 \\
\hline Public education & $1.00(100)$ & 0.84 \\
\hline Citizen involvement & $0.98(98)$ & 0.80 \\
\hline Seminars for developers and builders & $0.17(17)$ & 0.50 \\
\hline Hazard disclosure requirements in real estate transactions & $0.13(13)$ & 0.50 \\
\hline Hazard zone signs & $0.13(13)$ & 0.42 \\
\hline Requirements for locating public facilities and infrastructure & $0.37(37)$ & 0.56 \\
\hline Requirements for locating critical private facilities & $0.35(35)$ & 0.56 \\
\hline Using urban service areas to limit development & $0.93(93)$ & 0.53 \\
\hline Lower tax rates for preservation & $0.93(93)$ & 0.52 \\
\hline Special tax assessment districts & $0.65(65)$ & 0.52 \\
\hline Impact fees & $0.50(50)$ & 0.52 \\
\hline Land trusts & $0.89(89)$ & 0.52 \\
\hline Public-private partnerships & $0.57(57)$ & 0.50 \\
\hline Suitable building sites in hazard prone areas & $0.43(43)$ & 0.50 \\
\hline Special building techniques for hazard prone areas & $0.35(35)$ & 0.50 \\
\hline Identify stakeholders and their interests & $0.54(54)$ & 0.52 \\
\hline Coordination with other plans & $0.91(91)$ & 0.51 \\
\hline Coordination with surrounding and regional organizations & $1.00(100)$ & 0.57 \\
\hline Coordination with state or federal agencies & $1.00(100)$ & 0.62 \\
\hline Coordination with private organizations or NGOs & $0.70(70)$ & 0.52 \\
\hline Designation of responsibility & $0.54(54)$ & 0.64 \\
\hline Clear timetable for implementation & 0.59 (59) & 0.57 \\
\hline Necessary technical assistance & $0.24(24)$ & 0.50 \\
\hline Reliable financial support & $0.22(22)$ & 0.55 \\
\hline Regular monitoring, review and updating & $0.98(98)$ & 0.81 \\
\hline Amendment procedures & $0.39(39)$ & 0.56 \\
\hline
\end{tabular}

\subsubsection{Information dissemination strategies}

Local coastal zone land use plans have strong public, landowner, and continuing professional education programs for public education (100\%) and citizen involvement (98\%) to disseminate relevant coastal information. However, more specific strategies were not mentioned in these plans and only few plans specified seminars on coastal zone management practices for developers and builders $(17 \%)$, hazard disclosure requirements in real es- 
tate transactions $(13 \%)$ or setting special coastal zone signs (13\%). Based on the breadth and depth scores, local coastal zone land use plans usually generalized education programs or public participation programs, but less detailed approaches have been suggested or adopted in current information dissemination strategies.

\subsubsection{Critical and public facilities policies}

Although CZMA paid special attention to critical and public facilities, surprisingly, less than half of jurisdictions made special requirements for locating public facilities and infrastructure $(37 \%)$, critical private facilities and infrastructure in less specific coastal areas (35\%). However, $93 \%$ of jurisdictions used urban service areas to limit development in specific coastal areas. From the depth scores, approximately half the plans mandated critical and public facilities policies.

\subsubsection{Financial tools}

Most (93\%) used lower tax rates for preserving specific coastal areas as open space or limited development intensity. Approximately half $(65 \%)$ of the plans made special tax assessment districts for specific coastal zone areas. Only $50 \%$ used impact fees or special assessments for development of environmentally sensitive or hazardous areas. The relatively low depth scores for these items indicate that the financial tools are usually suggested by local jurisdictions in coastal zone land use plans. This result is partially consistent with some previous findings that showed that capital facilities and market-based mechanisms (e.g. concurrency, differential taxation) were rarely included, and were only suggested [1]. In this study, financial tools received some coverage, but were still at a lower level.

\subsubsection{Private-sector initiatives}

Land trusts have been adopted by $89 \%$ of local plans to protect environmentally sensitive or hazardous areas. However, only half (57\%) of them built public-private partnerships for environmentally sensitive or hazardous areas. Relatively few coastal plans specified using private geological or engineering consultants to determine suitable building sites in hazard prone areas (43\%), and special building techniques for hazard prone areas (35\%). The lower depth scores indicate that private-sector initiatives may only be suggested in local coastal zone land use plans.

\subsection{Indicator performance in coordination component}

Inter-organizational coordination simply means that coastal zone planning agencies must coordinate with one another before making land use decisions. All plans emphasized coordinating with state, federal agencies, or surrounding and regional organizations (bays, estuaries, watersheds). Ninety-one percent of the plans emphasized coordination with other plans (e.g. special area plans, transportation plans), and $70 \%$ coordinated with private organizations or NGOs. Approximately half (54\%) of the plans identified stakeholders and coastal zone land use plan interests. The depth scores for the indicators in the coordination component are between 0.50 and 0.62 , indicating many coastal jurisdictions did not mandate coordination procedures in coastal zone land use plans.

\subsection{Indicator performance in implementation and monitoring component}

The component of implementation and monitoring can measure the ability of a plan to implement policies, tools, and strategies. The most successful plans are those that were initially written with a concern for realistic and well-timed implementation. Although most (98\%) plans identified regular monitoring, review and updating procedures, many other indicators received lower breadth and depth scores. Fifty-nine percent of the counties pro- vided a clear timetable for plan implementation, and 39\% further identified plan amendment procedures. Fifty-four percent of jurisdictions designated specific responsibility for plan implementation, and only $24 \%$ specified resources for necessary technical assistance. Moreover, 22\% of the plans identified reliable financial support for the plan's implementation. Many plans have mandated procedures for regular monitoring, review and updating; this received the highest depth scores in the implementation component; however, the depth scores of other indicators for plan implementation are low.

\subsection{Regression results for independent variables}

The regression results for four sets of independent variables are listed in Table 4.

\subsubsection{Planning capacity results}

The results of the regression analysis for planning capacity variables suggest that the number of planners and integrated coastal management efforts make a statistically significant contribution to coastal zone land use plan quality.

Number of planners has a statistically $(p=0.002)$ positive impact on coastal zone land use plan quality. A large number of planners can bring more human resources, expertise and personnel to the local land use plan's coastal zone land use planning process; therefore, more planners may lead to higher quality coastal zone land use plans. More qualified planners create a higher quality coastal plan, particularly in the technically-driven aspects such as environmental impact analysis.

Integrated coastal management efforts show statistical significance $(p=0.000)$ with plan quality. The plan quality in the jurisdictions with integrated coastal management programs or special stand-alone coastal plans is statistically more significant than others

Table 4. Regression results

\begin{tabular}{|c|c|c|c|c|}
\hline Independent variables & Coefficient & $\begin{array}{l}\text { Standard } \\
\text { Coefficient }\end{array}$ & $t$-Value & $p$-Value \\
\hline Number of planners & 0.119 & 0.449 & 3.342 & $0.002^{*}$ \\
\hline Plan updating ability & 0.101 & 0.106 & 0.853 & 0.399 \\
\hline Information management & 1.014 & 0.107 & 0.912 & 0.367 \\
\hline Professional technical skill & 0.527 & 0.119 & 1.024 & 0.312 \\
\hline $\begin{array}{l}\text { Special coastal management } \\
\text { efforts } \\
\qquad \begin{array}{l}N=46 \\
\\
F \text {-ratio }(5,40)= \\
\text { Significance }=\end{array}\end{array}$ & $\begin{aligned} & 7.816 \\
= & 9.035 \\
= & 0.000\end{aligned}$ & 0.518 & 4.490 & $0.000^{*}$ \\
\hline $\begin{array}{l}\text { Critical environmental lands } \\
\text { Shoreline length } \\
\text { Land development pressure } \\
\text { Impact of population growth } \\
\qquad \begin{array}{r}N=46 \\
\text { F-ratio }(4,41) \\
\text { Significance }=\end{array}\end{array}$ & $\begin{aligned} & 0.227 \\
& 0.002 \\
&-1.943 \mathrm{E}-05 \\
&-0.091 \\
&= 8.853 \\
&= 0.000\end{aligned}$ & $\begin{array}{r}0.679 \\
0.021 \\
-0.050 \\
-0.196\end{array}$ & $\begin{array}{r}3.766 \\
0.127 \\
-0.363 \\
-1.705\end{array}$ & $\begin{array}{l}0.001^{*} \\
0.900 \\
0.718 \\
0.096\end{array}$ \\
\hline $\begin{array}{l}\text { Public participation format } \\
\text { Public notice channel } \\
\text { Public participation incentives } \\
\qquad \begin{array}{l}N=46 \\
\text { F-ratio }(3,42)= \\
\text { Significance }=\end{array}\end{array}$ & $\begin{aligned} & 0.785 \\
& 1.261 \\
\text { es } & 0.303 \\
& \\
= & 3.271 \\
= & 0.030\end{aligned}$ & $\begin{array}{l}0.158 \\
0.309 \\
0.050\end{array}$ & $\begin{array}{l}0.968 \\
1.847 \\
0.327\end{array}$ & $\begin{array}{l}0.339 \\
0.072 \\
0.746\end{array}$ \\
\hline $\begin{array}{l}\text { Population in } 2007 \\
\text { Wealth } \\
\text { Education } \\
\text { Land area } \\
\text { Jurisdiction type } \\
\qquad \begin{array}{l}N=46 \\
\\
\qquad \text {-ratio }(5,40)= \\
\\
\text { Significance }=\end{array}\end{array}$ & $\begin{aligned} & -1.641 \mathrm{E}-07 \\
& 2.760 \mathrm{E}-05 \\
& 0.005 \\
& 0.001 \\
& 6.381 \\
& \\
= & 5.228 \\
= & 0.001\end{aligned}$ & $\begin{array}{r}-0.041 \\
0.094 \\
0.009 \\
0.219 \\
0.491\end{array}$ & $\begin{array}{r}-0.279 \\
0.434 \\
0.044 \\
1.152 \\
2.858\end{array}$ & $\begin{array}{l}0.782 \\
0.667 \\
0.965 \\
0.256 \\
0.007^{*}\end{array}$ \\
\hline
\end{tabular}

* Significant at 0.01 level. 
without them. Developing integrated coastal management programs or special stand-alone coastal plans can consolidate multiple efforts to improve plan quality.

Plan update ability did not show a statistical impact on coastal zone land use plan quality, but did show a positive influence on plan quality. The effect of professional technical skill is not significant although it would be expected that professional technical skill would increase the quality of the plan while controlling for other planning capacity variables.

\subsubsection{Environmental sensitivity result}

Critical coastal lands present a significant correlation $(p=0.001)$ with coastal zone land use plan quality. Local jurisdictions with more critical coastal lands devote more effort to protect them that can lead to stronger coastal zone land use planning capacities. Local jurisdictions with more critical lands play an important role in local natural resources, open space, ecosystem, biodiversity, recreation and education by devoting more financial resources, personnel, management capacities, and collaborative efforts with multiple organizations in coastal management. Thus, a jurisdiction with more critical coastal lands will tend to have a higher quality of coastal zone land use planning.

Neither increased development pressure nor the impact of population growth showed significance with coastal zone land use plan quality, but indicated a certain non-significant negative impact on local coastal zone land use plan quality. The jurisdictions with increased development pressures in housing development or rapid population growth devoted less effort and commitment to coastal zone land use planning. Increased development pressure and the impact of population growth can consume more resources and place greater pressure on coastal areas; it also creates more waste and pollution. On one hand, these jurisdictions may also have limited space to negotiate with land developers to protect critical coastal resources and coastal environmental quality; on the other hand, they have to spend a great deal of time and energy addressing population and development pressures and solving potential coastal conflicts.

The length of shorelines did not have a directly significant influence on coastal zone land use plan quality. Jurisdictions with longer shorelines did not naturally produce higher coastal zone land use plans.

\subsubsection{Public participation result}

In regard to public participation capacity variables, no variable made a statistically significant contribution to coastal zone land use plan quality. While public participation variables did not have a statistically significant impact on coastal zone land use plan quality, these variables have a certain influence on coastal zone land use plan quality.

Public participation is a difficult issue since it is technically not possible to expect participation from political, economic, technical and wide-ranging sources. Public participation processes are criticized as ineffective by participants, costly, and time consuming, by proponents, and inefficient by governments. This regression result shows that effectively translating public participation efforts into practical coastal zone land use planning is thereby a critical issue for both planning agencies and coastal management agencies. This result indicates that a greater number of participation formats, public notice channels, or public participation incentives do not result in high quality coastal zone land use plans.

Although many articles have highlighted the influence of public participation on land use planning outcomes [40], no variable was statistically significant in this study. This study indicated that it is difficult to reflect public participation capacity in local coastal zone land use planning products. The jurisdictions with stronger public participation may not have a better coastal zone land use plan; however, public participation is a positive influence on the coastal zone land use plan quality. The result identified a gap between public participation efforts and final coastal zone land use plan quality. Although past studies [41] have shown the importance of public participation on local land use planning, this study did not find the statistical evidence to support the hypothesis that stronger public participation can result in higher coastal zone land use plan quality. However, public participation may help cope with uncertainty and conflict and facilitate effective joint participation through identifying stakeholders' interests, building more transparent decision-making processes, more creative dispute solving and greater public involvement; it may also result in a longer duration for decision-making and a costly coastal zone land use planning process. In addition, different stakeholders have various levels of power and resources to affect the decision-making process by placing unequal impacts on the decisions in coastal zone land use plans. Thus, it is difficult to ensure absolute equity in the distribution of benefits and harm resulting from the coastal zone land use planning and enhance a mutual adjustment in the development process. More important, public participants generally pay close attention to their own interests because of "not-in-my-backyard" and "locally unwanted-land-use attitudes" [43]. Public interest tends to focus on more tangible development proposals in local neighborhoods rather than abstract, comprehensive and longterm development proposals [44]. Finally, various public participation techniques may have an opposite influence on coastal zone land use plan quality, thus the mixed number of public participation types cannot appropriately explain the influence of public participation capacity on coastal zone land use plan quality.

\subsubsection{Contextual characteristics result}

Among the contextual characteristics variables, only jurisdiction type is statistically significant ( $p=0.007)$. Coastal counties have higher coastal planning quality than coastal municipalities. Comparing plan quality between coastal counties' plans and coastal municipalities' plans, the statistical results show that the quality of local coastal zone management plans $(M=28.17)$ is statistically $(p=0.000)$ higher than the quality of the coastal zone management section in local comprehensive plans $(M=20.26)$.

Population did not show significance with coastal plan quality, but did indicate a negative impact. The jurisdictions with larger population often have more coastal pressure and conflicts that result in higher levels of disturbance to the coast. Potential land use conflicts result in a greater demand for land development in sensitive coastal areas. Income, education, land areas all suggest positive relationships with coastal zone land use plan quality even if they are not statistically significant. In summary, findings reveal important insights into the influences of local coastal zone land use plan quality. Additionally, these results are useful for informing local planning activities.

\section{Policy implications}

This study also adds to the practice of managing local coastal zones through the following land use planning policy implications.

The first policy recommendation is for planners to integrate upper-scale coastal management efforts and build a solid factual basis for their plans. The descriptive results show that local coastal zone land use plans often did not have a very strong, solid, detailed factual basis although many indicators were covered in these plans. Coastal zone data and technical information can improve coastal planning's factual basis which is generally considered to be the foundation of a plan. A stronger factual basis will also increase a local jurisdiction's awareness of coastal problems and the need to install protective measures. Having a better un- 
derstanding of and stronger identification for critical coastal elements and tools will help planners take a more proactive stance in coastal management. In fact, a vast body of information regarding coastal management is available at regional, state and federal levels. Local jurisdictions should make the maximum possible effort to use the extensive existing coastal information to update their plan's factual basis. Most of this information is free-to-use, webbased, and GIS-based; thus, it is easy to adopt for local plans. Local jurisdictions should reexamine and update their own coastal zone land use plans when important changes are made in regional or adjacent plans.

The second recommendation is to develop stronger implementation and monitoring mechanisms. The implementation and monitoring plan component received the lowest scores in these five plan components. Many local jurisdictions failed to identify appropriate implementation and monitoring mechanisms. It is an essential part of local coastal planning which enables the plan to be a flexible policy instrument and ensure that a local coastal zone land use plan can effectively practice adaptive management. Lack of implementation and monitoring mechanisms in these programs has placed even greater pressure on coastal resources and coastal land development. Since local coastal zone land use planning should be dynamic, it should reflect changes and continually monitor the relevance of plan elements to ensure that they remain in touch with evolving conditions. Local jurisdictions should improve plan performance at the local level and establish a stronger link between plan content and plan implementation to enhance plan's implementation and monitoring. Local jurisdictions must establish formal procedures for regularly monitoring the effectiveness of their plans. When a monitoring program reveals a plan inadequacy, plans should be amended or revised in order to bring them up to date. It is not only important to identify critical coastal resources, but also to monitor changes on baseline conditions over time.

The third recommendation is that local jurisdictions should expand the planners' toolbox to provide clear policy directives and specific coastal management tools. While regulatory policies such as land use permits, land use restrictions and sensitive land protection are most frequently adopted by existing local jurisdictions; non-regulatory strategies are often omitted in many current plans. These non-regulatory tools can encourage stakeholders to think about and to improve the plan quality rather than force them to protect coastal resources. New approaches for coastal management should be considered in existing coastal zone land use planning. In fact, coastal zone land use planning and protection does not exist in a vacuum, and local jurisdictions need to combine regulatory policies, incentive tools, land acquisition programs, communication-based policies, and other approaches into a whole toolbox. Other policies, tools and strategies can be used effectively to supplement regulations to provide a relatively permanent way to manage coastal zones.

The fourth recommendation is that local jurisdictions need to develop integrated coastal management programs or special standalone coastal zone land use plans to integrate multiple local coastal management efforts. An important issue for coastal zone land use planning thus becomes finding ways to motivate local jurisdictions to protect critical coastal resources before they are lost to development. Since traditional project-by-project coastal zone land use planning is inadequate for long-range, holistic consideration, integrated coastal management programs or special standalone coastal zone land use plans can provide a long-term perspective. Local agencies should improve the old management model that tends to consider daily activities such as zoning and subdivision over long-term strategic planning. Integrated coastal management efforts can help local planning agencies improve coastal zone land use plan quality by solving numerous problems and conflicts as early in the planning process as possible.

The fifth recommendation is to educate planners, decision makers, and the general public to reach a better understanding of coastal zones. This study found that planners and critical coastal lands statistically contribute to local coastal zone plan quality. It is imperative to educate planners, decision-makers, and the general public about critical coastal resources and coastal issues in local land use planning since the plan itself focuses on local future sustainable development.

The sixth recommendation is to enhance the effectiveness of public participation. It is critical to effectively transfer public participation efforts into final coastal zone land use planning outcomes. Although none of the variables of public participation was significant, it still gives us a chance to rethink and reexamine this core planning theory in coastal zone land use planning.

Although this study provides a greater understanding of local coastal zone land use plan quality and the factors influencing it, it is a primer for research to investigate the topic in California. This study has several limitations. The sample size of 46 plans is limited for multiple regression analysis even though this research collected data from all coastal counties and approximately half of the coastal municipalities in California. The impact of possible influential data points may disturb the conclusions of this study. In addition, the difficulty in expressing the dynamic process of local coastal zone land use planning is actually reflected in final plan quality. Finally, while this study's results want to be extended to other places, geographical variations, socioeconomic characteristics, and policy framework can be external validity threats. A future study will conduct a questionnaire survey among local coastal planning directors to further examine more variables that may influence local coastal zone land use plan quality.

\section{Acknowledgments}

The author gratefully appreciates the anonymous reviewers for Ocean \& Coastal Management, whose comments greatly improved this paper.

\section{References}

[1] Davis BC. Regional planning in the US coastal zone: a comparative analysis of 15 special area plans. Ocean \& Coastal Management 2004; 47(1-2):79-94.

[2] Burby RJ. Have state comprehensive planning mandates reduced insured losses from natural disasters? Natural Hazards Review 2005; 6(2):67-81.

[3] Allmendinger P, Barker A, Stead S. delivering integrated coastalzone management through land-use planning. Planning Practice and Research 2002; 17(2):175-96.

[4] Kay R, Alder J. Coastal planning and management. London: EF \& N Spoon; 1999. p. 1-380.

[5] Wescott G. The theory and practice of coastal area planning: linking strategic planning to local communities. Coastal Management 2004; 32(1):95-100.

[6] Archer JH, Knecht RW. The U.S. national coastal zone management programdproblems and opportunities in the next phase. Coastal Management 1987; 15(2):103-20.

[7] Brown AL, Therivel R. Principles to guide the development of strategic environmental assessment methodology. Impact Assessment and Project Appraisal 2000; 18(3):183-9.

[8] Godschalk DR. Implementing coastal zone management: 19721990. Coastal Management 1992; 20:93-116.

[9] Bernd-Cohen T, Gordon M. State coastal program effectiveness in protecting natural beaches, dunes, bluffs, and rocky shores. Coastal Management 1999; 27(2-3):187-217. 
[10] Good JW, Weber JW, Charland JW. Protecting estuaries and coastal wetlands through state coastal management programs. Coastal Management 1999; 27(2-3):139-86.

[11] Pogue P, Lee V. Providing public access to the shore: the role of coastal zone management programs. Coastal Management 1999; 27(2-3):219-37.

[12] Goodwin RF. Redeveloping deteriorated urban waterfronts: the effectiveness of U.S. coastal management programs. Coastal Management 1999; 27(2/3): 239-69.

[13] Hershman MJ. Seaport development and coastal management programs: a national overview. Coastal Management 1999; 27(2-3):271-90.

[14] Knecht RW, Cicin-Sain B, Fisk GW. Perceptions of the performance of state coastal zone management programs in the United States. II. Regional and state comparisons. Coastal Management 1997; 25(3):325-43.

[15] National Oceanic and Atmospheric Administration (NOAA). NOAA discussion paper: current and future challenges for coastal management, < http://coastalmanagementfinoaa.gov/czm/media/discussion paper.pdf $>$; 2006. p. 2-38 (visited on July 10, 2007).

[16] Berke PR, French SP. The influence of state planning mandates on local-plan quality. Journal of Planning Education and Research $1994 ; 13: 237-50$.

[17] Kaiser EJ, Godschalk DR. 20th-century land-use planning-A stalwart family tree. Journal of the American Planning Association 1995; 61:365-85.

[18] Brody SD. Implementing the principles of ecosystem management through local comprehensive landuse planning. Populationand Environment 2003; 24:511-40.

[19] Brody SD. Examining the role of resource-based industries in ecosystem approaches to management: an evaluation of comprehensive plans in Florida. Society and Natural Resources 2003; 16:625-41.

[20] Brody SD. Are we learning to make better plans? A longitudinal analysis of plan quality associated with natural hazards. Journal of Planning Education and Research 2003; 23:191-201.

[21] Brody SD. Measuring the effects of stakeholder participation on the quality of local plans based on the principles of collaborative ecosystem management. Journal of Planning Education and Research 2003; 22:407-19.

[22] NelsonAC, French SP. Plan quality and mitigating damage fromnatural disasters: a case study of the Northridge earthquake with planning policy considerations. Journal of the American Planning Association 2002; 68(2):194-207.

[23] Norton RK. Local commitment to state-mandated planning in coastal North Carolina. Journal of Planning Education and Research 2005; 25(2):149-71.

[24] Pollnac RB, Pomeroy RS. Factors influencing the sustainability of integrated coastal management projects in the Philippines and Indonesia. Ocean \& Coastal Management 2005; 48:233-51.

[25] Olshansky RB. Land use planning for seismic safety: the Los Angeles County experience, 1971-1994. Journal of the American Planning Association 2001; 67(2):173-85.
[26] National Oceanic and Atmospheric Administration (NOAA). report to congress on national coastal management performance measurement system, < http://coastalmanagementfinoaa.gov/resources/docs/ncmpms_congress.pdf $>$; 2006. p. 1-48 (visited on July 10, 2007).

[27] Vellinga P, Klein RJT. Climate-change, sea-level rise and integrated coastal zone management - an ipcc approach. Ocean \& Coastal Management 1993; 21(1-3):245-68.

[28] Olshansky RB, Kartez JD. Managing land use to build resilience. In: Burby RJ, editor. Cooperating with nature: confronting natural hazards with comprehensive land use planning for sustainable communities. Washington, DC: Joseph Henry Press; 1998. p. 167-202.

[30] Brody SD, Highfield W, Carrasco V. Measuring the collaborative planning capabilities of local jurisdictions to manage ecological systems in southern Florida. Landscape and Urban Planning 2004; 69:33-50.

[31] Kartez JD, Lindell MK. Planning for uncertainty: the case of local disaster planning. Journal of the American Planning Association 1987; 53(4):487-9.

[32] Lindell MK, Meier MJ. Effectiveness of community planning for toxic chemical emergencies. Journal of the American Planning Association $1994 ; 60: 222-34$.

[33] Vanderhaegen M, Muro E. Contribution of a European spatial data infrastructure to the effectiveness of EIA and SEA studies. Environmental Impact Assessment Review 2005; 25(2):123-42.

[34] Scott D, Willits FK. Environmental attitudes and behavior. Environmental Behavior 1994; 26(2):239-61.

[35] Van Liere KD, Dunlap RE. Environmental concern _ does it make a difference how it's measured? Environmental Behavior 1981; 13:651-76.

[36] Guagano GA, Markee N. Regional differences in the sociodemographic determinants of environmental concern. Population and Environment 1995; 17(2):135-49.

[38] California Office of Planning and Research. Governor's environmental goals and policy report. Governor's office of planning and research. Sacramento: California Office of Planning and Research; 2003. p. 20-40.

[39] Lee EM. The political ecology of coastal planning and management in England and Wales - policy responses to the implications of sea-level rise. Geographical Journal 1993; 159:169-78.

[40] Godschalk DR, Brody SD, Burry R. Public participation in natural hazard mitigation policy formation: challenges for comprehensive planning. Journal of Environmental Planning and Management 2003; 46(5):733-54

[41] Healey P. A planners day _ knowledge and action in communicative practice. Journal of the American Planning Association 1992; 58:9-20.

[43] Fischer TB. Strategic environmental assessment in post-modern times. Environmental Impact Assessment Review 2003; 23:155-70.

[44] Altshuler A. The goals of comprehensive planning. Journal of the American Institute of Planners 1965; 31:186-95. 